\title{
CONSEQUENTIALITY BELIEFS AND CONSUMER VALUATION OF EXTRINSIC ATTRIBUTES IN BEEF
}

\author{
XIAOGU LI \\ Department of Agricultural Economics, Sociology, and Education, Pennsylvania State University, University Park, \\ Pennsylvania \\ KIMBERLY L. JENSEN* \\ Department of Agricultural and Resource Economics, University of Tennessee, Knoxville, Tennessee \\ DAYTON M. LAMBERT \\ Department of Agricultural and Resource Economics, University of Tennessee, Knoxville, Tennessee \\ CHRISTOPHER D. CLARK \\ Department of Agricultural and Resource Economics, University of Tennessee, Knoxville, Tennessee
}

\begin{abstract}
This study measures willingness to pay (WTP) for extrinsic attributes (Angus, local, DNA traceable, raised carbon friendly, and humanely treated cattle) in steak and ground beef using choice-based experiments from a national consumer survey. Belief that survey responses could have consequences on beef products offered by the steak and ground beef industry is investigated, as well as its effect on attribute WTP. For most attributes, belief in consequentiality increases WTP. Results suggest that although consequentiality believers tend to place greater importance on certain food industry issues, they are less certain about the attribute's provision actually effecting change in the industry.
\end{abstract}

Keywords. Consequentiality, contingent choice experiments, extrinsic attributes

JEL Classifications. D12, Q13

\section{Introduction}

Many nontaste attributes are credence attributes. Credence attributes are undiscernible to consumers even after purchase and consumption of the good (Darby and Karni, 1973; Loureiro and Umberger, 2007). Retailers and meat-processing companies use certification or information labels to convey information about an underlying policy, promotion, or industry-based program.

This work was supported in part by a grant from the U.S. Department of Agriculture, National Institute of Food and Agriculture, Agriculture and Food Research Initiative Competitive Grants Program (Grant No. GRANT10642663). The views expressed in this article are solely those of the authors.

*Corresponding author's e-mail: kjensen@utk.edu 
Thus, labeling credence attributes can reduce information asymmetry between consumers, retailers, and meat processors (Clark and Russell, 2005; Kennedy, Laplante, and Maxwell, 1994). Willingness-to-pay (WTP) for labeled products is likely influenced by consumer beliefs that the labeling scheme will alter the provision, or provision mechanism, of an underlying public or private good. An example is whether certification of humane animal treatment will engender the use of more humane management practices on the farm and throughout the processing chain. Another example is when consumers choose to purchase locally produced beef products because they believe these products will be fresher and healthier or because they believe reduced food miles result in lower greenhouse gas (GHG) emissions.

Demand choices may also be influenced by consumer beliefs about the consequentiality of their choice on the provision of an associated private or public good that may be affected by beef producers and processors, policy makers, or other market participants (Carson, Groves, and List, 2014; Herriges et al., 2010; Interis and Petrolia, 2014; Loomis, 2014; Vossler and Watson, 2013). More specifically, in empirical studies using stated preference methods, the stated values of respondents who believe their choices have consequences on policy or some related behavior are more likely to follow rational economic decision making. In some cases, premiums for specific attributes may be higher (Carson, Groves, and List, 2014; Herriges et al., 2010; Vossler and Watson, 2013; Vossler, Doyon, and Rondeau, 2012). Additionally, research by Hwang, Petrolia, and Interis (2014) found that respondents who do not believe the survey will be consequential were more likely to opt out than to vote "yes" in multinomial choice formats.

In the context of a stated choice experiment for beef wherein the label implies additional provision of public or private goods, consumers' belief in the consequentiality of their survey choices and the influence of these beliefs on WTP for the labeled attribute may represent several conditional decisions. The first is the degree to which respondents have confidence industry agents will correctly interpret and translate their preferences into beef productsfor example, offering humane treatment certification labels. The second is how respondents value the public or private good outcome-for example, the weight they place on locally produced goods and the expected impacts on local economies. The third context is respondents' belief that their purchase of the labeled attribute will support or reinforce the label subject-for example, whether a traceability label will result in a safer food supply chain.

Numerous labeling programs associated with beef products encompass credence attributes. Examining specific attributes among an array of possible attributes provides a direct, multidimensional comparison of WTP. Consequentiality beliefs may vary in their effect on WTP depending on the type of extrinsic attribute-for example, environmental effects, food safety concerns, or the humane treatment of animals (Henchion et al., 2014). Direct comparison 
also generates WTP contrasts of how consequentiality beliefs affect WTP across different public or private good labels.

This study examines (1) consumer WTP for multiple nontaste beef attributes whereby labels represent underlying public or private goods and (2) consumer beliefs about the consequentiality of their participation in a hypothetical market for beef and the impact of these beliefs on attribute-specific WTP. The attributes were selected to represent labels that may be of interest to beef cattle producers, beef processors, third-party certifiers, and consumers. For example, McGarry Wolf and McLennan (2017) found that consumers demanding meat products purchased local brands because of quality but also because of proximity to their home. The food safety of beef served through the U.S. Department of Agriculture's (USDA) National School Lunch Program is a continuing public concern receiving periodic attention in the media (Ollinger, Guthrie, and Bovay, 2014). Higher consumer income also correlates positively with demand for animal products raised using humane practices or more stringent sanitary standards (Halbrook, Armbruster, and Thompson, 2006). Popular sources indicate demand for grass-fed beef continues to increase at an annual rate of $25 \%$ to $30 \%$ (Bussard, 2016) as consumers seek "cleaner" or more natural beef alternatives (Aylward, 2015). Consumer preferences for safe meat products have also driven innovation in equipment sanitizing and testing protocols by beef suppliers (Golan, Roberts, and Ollinger, 2004), as well as advances in methods to trace food through the food supply system (Golan, Kissoff, and Kuchler, 2004). Interest in these topical issues continues to grow among consumers, in turn garnering attention by the food retail sector and meat processors. The specific attributes listed previously encompass features with primarily private benefits, primarily public benefits, and some with a mixture of public and private benefits. Certified Angus (Angus) represents a well-known attribute with primarily private benefits. In contrast, the attributes for beef cattle raised using GHG-reducing grazing practices (Carbon) and humanely treated animals (Humane) generate public benefits. The attributes for locally produced (Local) and DNA traceable (Traceable) beef embody public and private benefits.

Respondents surveyed in this study were also asked if they believed their responses would persuade the beef cattle industry to augment the array of beef products offered. The interaction between consumer belief in consequentiality and the WTP levels is examined. The interaction with the attributes enables measurement of the effects of beliefs about consequentiality on industry product offerings on WTP for labeling programs potentially affecting environmental practices, humane treatment of cattle, local products, and food safety practices. The attributes examined include a range of both public and private benefits to the environment, local farmer incomes and economies, animal welfare, and food safety. These topical issues are used to demonstrate differences in WTP for extrinsic attributes as well as differences across beliefs in consequentiality (i.e., the respondent's perception of how their consumptive behavior will shape the 
product market landscape). Ex post analyses measure how respondents value the underlying issues related to the hypothetical labeling program relative to maintaining low food prices and the extent to which respondents perceive that the presence of an attribute will further an underlying objective, such as the purchase of local foods supporting local farmers and economies. These values and perceptions are subsequently compared across respondent beliefs in the consequentiality of their responses.

\subsection{Previous Research}

\subsubsection{Belief in Consequentiality}

A major empirical challenge facing hypothetical choice experiments is that the choices offered to respondents may have little influence on their expected quality of life (Carson, Groves, and List, 2014). Carson and Groves (2007) term these choices as inconsequential in contrast to a consequential survey choice where the respondent perceives a positive probability of influencing an outcome in which the respondent is emotionally or monetarily invested. Some language intended to convince respondents that their responses will influence agency decisions and policy making is often included in hypothetical choice surveys. If respondents believe their responses will have consequence, their responses may more closely match revealed preferences.

Numerous studies have examined the effects of consequentiality on stated preferences for public projects and policies. Herriges et al. (2010) investigated whether responses were influenced by beliefs that a survey would influence policy regarding a water quality improvement project. Herriges et al. found undistinguishable WTP distributions among respondents who believed that the survey would have at least some minimal consequence. However, Herriges et al. found that respondents who believed the survey would not affect policy exhibited a statistically lower WTP distribution. Vossler and Watson (2013) examined a referendum for a conservation program funded by a local property tax. The researchers controlled for referenda-related information effects and perceptions about consequentiality by leveraging respondent naïveté about the upcoming referendum. Vossler and Watson's WTP analysis demonstrated that respondents who did not consider the survey to be consequential had a statistically lower stated WTP. Vossler, Doyon, and Rondeau (2012) examined a decision for tree-planting efforts in Quebec, Canada. They examined the effect of indirect policy consequences whereby participant votes would influence broader policy decisions. Vossler et al. found that incentives are important even in a stated preference survey where financial consequences are remote and the payment mechanism is vaguely articulated. Nepal, Berrens, and Bohara (2009) constructed four indices of perceived consequentiality, examining how these variables influenced U.S. household WTP to mitigate climate change. They found consequentiality positively affected WTP for climate change mitigation efforts. 
Groothuis et al. (2017) found that consumers who believed their survey responses were consequential exhibited higher WTP for water conservation in western North Carolina.

As Interis and Petrolia (2014) discuss, prior research analyzing consequentiality effects on WTP have primarily used binary referenda. Interis and Petrolia incorporated consequentiality into an analysis of coastal wetland and barrier island restoration in Louisiana's Barataria-Terrebonne National Estuary. They examined WTP for three attributes: improved wildlife habitat, storm surge protection, and commercial fish harvest. They found that respondents who believed the results were more likely to influence future policy were willing to pay more for higher attribute levels. They also found that only respondents who believed that the survey results would be at least somewhat likely to affect future policy behaved consistently with theoretical predictions in the choice experiment.

Other empirical examples generally examine referenda for payments or taxes levied to fund public good projects and, in many cases, for improvement of the environment or natural resource base. This study examines product labeling for attributes associated with programs that could simultaneously affect several public goods, including animal welfare, the environment, food safety, local economies, and farmer income. The analysis focuses on the effects of consequentiality beliefs on ground beef and steak purchasing decisions.

\subsubsection{Studies of WTP for Extrinsic Attributes}

Several studies find WTP premiums for Angus-certified steaks (Feldkamp, Schroeder, and Lusk, 2005; Froehlich, Carlberg, and Ward, 2009; Lusk and Schroeder, 2004). Previous research also finds WTP premiums for locally produced beef (Adalja et al., 2015; Chang et al., 2013). Results from consumer preference studies on enhanced traceability for beef and other food products are mixed. Verbeke and Ward (2006) and Steiner, Gao, and Unterschultz (2010) did not find evidence of preferences for traceability. Doherty and Campbell (2014) found that British consumers would pay premiums for products with a government-issued certification label indicating the food products had "enhanced traceability." Hobbs, Bailey, and Haghiri (2005) and Lee et al. (2011) also found evidence of willingness to pay a premium for traceable beef. Cicia and Colantuoni (2010) conducted a meta-analysis of WTP for traceability of meat products across 23 studies. They found a marginal WTP percentage per each meat traceable attribute of $23 \%$ over a baseline price of $\$ 4.03$. In addition to food safety applications, traceability and information about animal genetics could also be viewed by consumers as indicators of beef quality (Vestal et al., 2013; Weaber and Lusk, 2010).

Consumers are also willing to pay for meat products from animals certified as humanely treated (Carlsson, Frykblom, and Lagerkvist, 2007; Dickinson, Hobbs, and Bailey, 2003; Lagervist and Hess, 2011; Lijenstolpe, 2008). Previous 
studies also found consumers willing to pay premiums for meat produced with reduced environmental impacts (Hurley, Miller, and Kliebenstein, 2006; Tonsor and Shupp, 2009). In a meta-analysis on estimates of consumer WTP for environmental impact-reducing technologies in meat production, White and Brady (2014) found that consumers would pay a $29 \%$ premium for environmental attributes (local, all natural, grass fed, organic) that had both public and egocentric benefits, versus a $14.8 \%$ premium for purely public benefits (e.g., GHG reductions).

Petrolia, Walton, and Yehouenou (2017) found that WTP for oysters was influenced by place of origin and production method (wild caught or farmed). Wild oysters brought a nearly $\$ 3$ per dozen premium. The effect of origin of oysters differed by location of respondents, with non-Gulf of Mexico respondents being likely to require a price discount on Gulf varieties relative to local varieties. They also found that respondents living near the Gulf were willing to pay a premium for branded Gulf varieties.

Several studies examined the relative influence of multiple attributes on WTP for beef. Abidoye et al. (2011) evaluated the effects of multiple attributes on U.S. beef consumer preferences. They found that traceability, origin, and animal feeding methods had the largest effect on WTP for steak. Mennecke et al. (2007) found that origin was most important, followed by animal breed, traceability, animal feed, and beef quality. Loureiro and Umberger (2007) found WTP was highest for certification of USDA food safety inspection, followed by country-of-origin labeling, traceability, and guaranteed tender products. Lusk, Roosen, and Fox (2003) examined differences in WTP for two credence goods in beef-genetically modified (GM)-free steaks and hormone-free steaks-across consumers from the United States and Europe (France, Germany, and the United Kingdom). Their study found that European consumers were willing to pay more for the GM-free steaks than U.S. consumers. For hormone-free steaks, U.S. consumer WTP fell below that of France and the United Kingdom. This research extends these previous studies by examining the impact of consequentiality beliefs on WTP for these attributes.

\section{Methods and Data}

Data were collected with an online survey of U.S. consumers hosted by GfK Custom Research LLC in November 2012. GfK recruits individuals aged 18 or older for its KnowledgePanel using a probability-based sample designed to represent the U.S. population. Households with a home computer and Internet access were asked to take GfK surveys using their own equipment and Internet connection. Households without a computer or access to the Internet were provided a laptop computer and free monthly Internet access in exchange for completing surveys. Panel members received incentive points for participating in the survey (Dennis, 2013). 
To qualify for participation in this study, a respondent or other household member had to prepare and consume beef at home. The number of surveys fielded was 3,187, of which 1,994 were completed before the opportunity for completing the survey was closed. There were 1,688 respondents qualified as preparers and consumers of beef at home. The survey completion rate was $63 \%$, and the qualification rate was $85 \%$.

The survey employed contingent choice analysis (Louviere, 1988), an extension of the contingent valuation method (Mitchell and Carson, 1989), an approach consistent with random utility theory (Adamowicz et al., 1998). Contingent choice experiments allow researchers to model respondent choice as a function of the attributes of a product or service (Vermeulen, Goos, and Vanderbroek, 2008). In these experiments, respondents are asked to complete a series of choices composed of selecting their most preferred alternative from sets of more than two alternatives that are differentiated by values for a common set of attributes. Choice sets were offered for two products: steak and ground beef. Respondents were assigned the steak (ground beef) version if they reported that at least one of the meals prepared in their home during a typical week included steak (ground beef) but not ground beef (steak). Respondents were randomly assigned to either the steak or the ground beef version of the survey if at least one meal included steak and at least one meal included ground beef. As part of the choice experiments, the extrinsic attributes (Angus, locally produced, DNA traceable, raised using carbon friendly practices, and humane treatment of cattle) that differentiated the product alternatives were introduced to the respondents with information screens explaining each attribute.

The Angus label was based on the USDA-certified Angus requirements (USDA, Agricultural Marketing Service [AMS], 2017a). The USDA definition of local was used in formulating the Local label. The USDA definition of local is that the beef is grown and processed within 400 miles of the location where the beef is sold or sold within the same state in which the cattle were grown and processed (Martinez et al., 2010). The Carbon label was defined as a voluntary labeling program that identifies beef products grown by producers using practices that reduce GHG emissions. An information screen was provided with information about beef cattle's contribution to GHG emissions as well as an example practice, prescribed grazing, that might help reduce GHG emissions (USDA, Natural Resources Conservation Service, 2010; U.S. Environmental Protection Agency, 2015). The Traceable label was defined as the ability to follow the movement of beef through the stages of production from the farm to the retail store (Moe, 1998). The description provided to respondents was based on the science surrounding genetic bar coding as a means for meat traceability (Galimberti et al., 2013) and a composite of several emerging industry provided systems. The specific language used was: “A cow's DNA provides a unique biological identifier for that animal. This identifier can be stored in a database available to handlers, processing facilities, and retail facilities that allows retailers to trace 
exactly where their beef is coming from." The label Humane was described as providing "independent third-party verification that the care and handling of beef cattle meet scientifically-based animal welfare standards from birth to processing." The definition was based on program specifications for humanely raised and handled animals from a composite of sources such as those adopted by the Humane Farm Animal Care (2017) for the Certified Humane Raised and Handled label, the Animal Welfare Approved (2017) label program, and the American Humane Certified label program (American Humane Association, 2017), as well as descriptions from previous research (Carlsson, Frykblom, and Lagerkvist, et al., 2007; Dickinson, Hobbs, and Bailey, 2003; Lagervist and Hess, 2011; Lijenstolpe, 2008).

The attribute information screens were followed by a screen reminding respondents of their household budget for food and the importance of considering their expenses in responding to the choice tasks (Cummings and Taylor, 1999; List, 2001; Loomis, 2014). The budget reminder screen for steak stated the following:

We are going to ask you to select among several steaks. Before you tell us which steak you prefer, we would like you to help us with a problem we have in studies like this one. People often do not pay much attention to the actual prices shown because they don't really have to pay the cost of the steak they say they prefer. Instead, they simply notice that one price is larger than another price. Along with the other steak attributes presented, please closely examine the steak prices and consider these in comparison to your household's food budget before choosing a particular steak.

The contingent choice experiments followed this budget reminder screen. (See the ground beef example screen in Figure 1). Because the focus of the analysis was on extrinsic attributes, respondents were asked to assume that the steak or ground beef alternatives are identical in all ways except for the extrinsic attributes they were asked to evaluate. The alternatives were presented as being identical in terms of the intrinsic characteristics of leanness, freshness, color, meat texture, juiciness, and flavor.

The contingent choice experiments consisted of 14 tasks, each requiring respondents to choose a single alternative from the beef products with combinations of price and extrinsic attributes. Respondents were allowed to opt out of each choice, with a "None. I would not buy any of these" option. The opt-out choice enables measurement of the effects on consumer choice of factors beyond the attributes offered in the choice sets (Adamowicz et al., 1998). In the estimated model, these effects are captured in the alternative specific constant (ASC). As noted by Adamowicz et al. (1998), the use of ASCs in choice models embodies status quo bias. If the ASC is omitted, the other model parameters would be confounded by this effect, resulting in biased attribute parameter estimates. 


\section{YOUR GROUND BEEF CHOICES}

The ground beef products you will be asked to select from are identical in all ways except for the attributes you will be asked to evaluate. Please imagine the ground beef products are identical in leanness, freshness, color, meat texture, juiciness, and flavor.

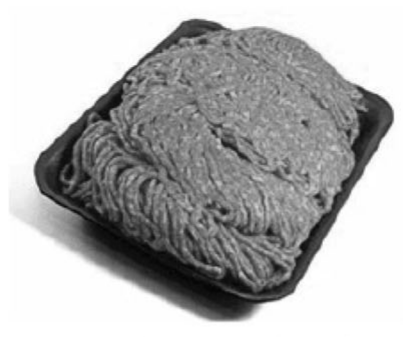

Pound of Ground Beef

If the following were your ground beef choices, which ground beef would you choose? Select one ground beef product at the bottom of this grid. Please note, the word "No" in a given attribute row means that the ground beef does not have that particular attribute.

\begin{tabular}{|c|c|c|c|c|}
\hline Attribute & Ground Beef 1 & Ground Beef 2 & Ground Beef 3 & \multirow{7}{*}{$\begin{array}{l}\text { None. I would not } \\
\text { buy any of these } \\
\text { ground beef } \\
\text { products. }\end{array}$} \\
\hline $\begin{array}{c}\text { USDA Angus } \\
\text { Certified }\end{array}$ & & & No & \\
\hline Local Beef & No & No & BEEF & \\
\hline $\begin{array}{c}\text { DNA } \\
\text { Traceable }\end{array}$ & No & & & \\
\hline $\begin{array}{l}\text { Raised } \\
\text { Carbon } \\
\text { Friendly }\end{array}$ & No & & & \\
\hline $\begin{array}{l}\text { Humane } \\
\text { Certified }\end{array}$ & & No & No & \\
\hline Price & $\$ 3.91$ & $\$ 2.35$ & $\$ 3.91$ & \\
\hline $\begin{array}{l}\text { Ground Beef } \\
\text { Product you } \\
\text { would } \\
\text { choose } \\
\rightarrow\end{array}$ & - & $\bullet$ & - & $\bullet$ \\
\hline
\end{tabular}

Figure 1. Example of Ground Beef Choice Task Screen

A total of 801 respondents completed the Steak choice tasks, and 887 respondents completed the Ground Beef choice tasks. Each individual was presented with 14 choice tasks and four alternatives per task. The number of observations was 44,564 for the Steak analysis and 49,068 for the Ground Beef analysis. The 14 choice tasks were randomized across each respondent. 
In addition to the extrinsic attributes, Price was an additional product attribute presented in each choice set. The midpoint prices for ground beef $(\$ 3.91)$ and steak (\$11.53) were based on U.S. average retail prices reported for these products by USDA-AMS (2017b) at the time of the survey launch. Distributions around these averages were formulated at $20 \%$ and $40 \%$ above and below the mean of five price levels for each product. The values of prices per pound for Steak were \$6.94, \$9.22, \$11.53, \$13.83, and $\$ 16.14$. For Ground Beef, the price points were $\$ 2.35, \$ 3.13, \$ 3.91, \$ 4.70$, and $\$ 5.48$.

After respondents completed the choice tasks, an opinion question was asked about how likely their responses to the survey would be to influence beef products offered. Response options were not very likely, somewhat likely, very likely, and no opinion. The Likert scale measuring consequentiality beliefs was combined into a dummy variable, Consequential, with a value of 1 if the respondent believed consequences were somewhat or very likely, and 0 otherwise. This indicator facilitated statistical comparison of WTP for the extrinsic beef attributes across consequentiality beliefs.

\section{Modeling Framework}

To accommodate potential scale and taste heterogeneity effects and to generate more precise WTP estimates, a generalized multinomial logit (GMNL) model adjusted for scale heterogeneity and estimated in WTP space was used (Hensher and Greene, 2011; Train and Weeks, 2005). A group identifier was used in the GMNL model to account for individual-repeated responses over multiple choice sets.

Taste heterogeneity implies that preferences for a particular product attribute or set of attributes vary across individuals (Train, 2003). Scale heterogeneity implies differences in the degree of certainty individuals have regarding their choices (i.e., some respondents are more certain about the relative utility levels associated with their choices than others) (Greene and Hensher, 2010, 2013; Train and Weeks, 2005).

Consumer choice of beef products can be modeled in the random utility framework (McFadden, 1994) and Lancaster's (1972) consumer utility maximization model such that each consumer $i$ derives utility $\left(\tilde{U}_{i j t}\right)$ by choosing a beef product $j$ from a set of $J$ alternatives in choice set $t$. Each alternative is defined and differentiated by a set of product characteristics or attributes. To accommodate taste and scale heterogeneity, the preference space model is reparameterized such that the outcome can be predicted through estimation of the probability that alternative $j$ is chosen in WTP space, with all parameters, including the cost parameter, random and the scale parameter varying across individuals. 
Table 1. Variable Names, Descriptions, and Means

\begin{tabular}{|c|c|c|c|}
\hline \multirow[b]{2}{*}{ Variable Name } & \multirow[b]{2}{*}{ Description } & \multicolumn{2}{|c|}{ Means } \\
\hline & & $\begin{array}{l}\text { Ground Beef } \\
\mathrm{N}=49,068\end{array}$ & $\begin{array}{l}\text { Steak } \\
\mathrm{N}=44,564\end{array}$ \\
\hline Price & Price per pound of steak or ground beef & 2.9666 & 8.7344 \\
\hline Angus & $\begin{array}{l}\text { Angus label: } 1 \text { if product labeled as Angus, } 0 \\
\text { otherwise }\end{array}$ & 0.3298 & 0.3230 \\
\hline Local & $\begin{array}{l}\text { Local label: } 1 \text { if product labeled as locally } \\
\text { produced, } 0 \text { otherwise }\end{array}$ & 0.3661 & 0.3659 \\
\hline Traceable & $\begin{array}{l}\text { Traceable label: } 1 \text { if product labeled as DNA } \\
\text { traceable, } 0 \text { otherwise }\end{array}$ & 0.3660 & 0.3659 \\
\hline Carbon & $\begin{array}{l}\text { Raised carbon friendly label: } 1 \text { if product } \\
\text { labeled as raised with carbon friendly } \\
\text { grazing management, } 0 \text { otherwise }\end{array}$ & 0.3833 & 0.3833 \\
\hline Humane & $\begin{array}{l}\text { Humane labeling: } 1 \text { if product labeled as } \\
\text { animal raised with humane treatment, } 0 \\
\text { otherwise }\end{array}$ & 0.3661 & 0.3661 \\
\hline$A S C$ & 1 if respondent chooses none, 0 otherwise & 0.2500 & 0.2500 \\
\hline Education & $\begin{array}{l}\text { Educational attainment level: } 1=\text { less than } \\
\text { high school, } 2=\text { high school graduate, } \\
3=\text { some college, } 4=\text { college graduate }\end{array}$ & 2.8294 & 2.8051 \\
\hline Consequential & $\begin{array}{l}\text { Likelihood that responses will affect beef } \\
\text { products offered: } 1=\text { somewhat or very } \\
\text { likely, } 0 \text { otherwise }\end{array}$ & 0.5087 & 0.5040 \\
\hline ConseqAngus & Consequential ${ }^{*}$ Angus & 0.1677 & 0.1640 \\
\hline ConseqLocal & Consequential* Local & 0.1865 & 0.1817 \\
\hline ConseqTraceable & Consequential*Traceable & 0.1861 & 0.1816 \\
\hline ConseqCarbon & Consequential*Carbon & 0.1951 & 0.1905 \\
\hline ConseqHumane & Consequential* Human & 0.1861 & 0.1822 \\
\hline ConseqASC & Consequential $^{*}$ ASC & 0.1272 & 0.1242 \\
\hline
\end{tabular}

\subsection{Taste and Scale Heterogeneity}

Incorporation of taste heterogeneity into utility with the multinomial logit framework (McFadden, 1994) implies

$$
\tilde{U}_{i j t}=\alpha_{i} \cdot P_{i j t}+\beta_{i}^{\prime} X_{i j t}+\varepsilon_{i j t} / \sigma_{i},
$$

such that $X_{i j t}$ represents the product attributes available in the $j$ alternatives in task $t$ (Table 1). In this study, these attributes include Angus, Local, Traceable, Carbon, and Humane. The parameters on the attributes, including price, were allowed to vary across individuals such that $\alpha_{i}=\bar{\alpha}+\eta_{i}$ and $\beta_{i}=\bar{\beta}+\eta_{i}, \bar{\alpha}$ and $\bar{\beta}$ are means, and $\eta_{i}$ a vector of individual i's deviations from these means. Following Train and Weeks (2005), utility, $\tilde{U}_{i j t}$, is reparameterized by multiplying both sides of utility by a scale parameter $\sigma_{i}$ :

$$
U_{i j t}=\sigma_{i}\left(-\alpha_{i} \cdot P_{i j t}+\beta_{i}^{\prime} X_{i j t}\right)+\varepsilon_{i j t},
$$


where $U_{i j t}=\tilde{U}_{i j t} / \sigma_{i}$.

If preference scaling is incorporated through $\sigma_{i}$ with an exponential transformation and allowed to be a function of individual characteristics, $Z_{i}$, then

$$
\sigma_{i}=\exp \left(\bar{\sigma}+\theta^{\prime} Z_{i}+\tau \cdot \varepsilon_{0 i}\right),
$$

where $\varepsilon_{0 i} \sim N(0,1)$ and $Z_{i}$ is a vector of characteristics. The parameter vector $\theta$ weights the importance of the individual factors in determining idiosyncratic scale effects. The constant $\bar{\sigma}$ is set at $-\tau^{2} / 2$, such that $E\left(\sigma_{i}\right)=1$ when $\theta=0$ (Fiebig et al., 2010). Substituting equation (3) into equation (2) for $\sigma_{i}$ yields

$$
U_{i j t}=\left[\exp \left(\bar{\sigma}+\theta^{\prime} Z_{i}+\tau \cdot \varepsilon_{0 i}\right)\left(-\alpha_{i} \cdot P_{i j t}+\beta_{i}^{\prime} X_{i j t}\right)\right]+\varepsilon_{i j t}
$$

(Hensher and Greene, 2011). Note that the degree of scale heterogeneity increases as the parameter $\tau$ increases.

Dummy variables representing task numbers (Task2, ..., Task14) and the respondent's level of education (Education) are included in the scaling portion of the model to explain determinants of preference certainty across choice sets. Education is a categorical measure of educational attainment coded as $1=$ less than high school, $2=$ high school graduate, $3=$ some college, or $4=$ college graduate. It is hypothesized that choice certainty is likely to be positively correlated with educational attainment. The task dummies are included to measure whether respondents become more (learning effects) or less (fatigue) certain about their preferences beyond the first task (Czajkowski, Giergiczny, and Greene, 2014).

\subsection{Conversion to WTP Space}

If WTP for an attribute is $\gamma_{i}=\beta_{i} / \alpha_{i}$ for all $i$, substituting this ratio into equation (4) and normalizing $\alpha_{i}=1$ yields

$$
U_{i j t}=\left[\exp \left(\bar{\sigma}+\theta^{\prime} Z_{i}+\tau \cdot \varepsilon_{0 i}\right)\left(-P_{i j t}+\gamma_{i}^{\prime} X_{i j t}\right)\right]+\varepsilon_{i j t}
$$

Equation (5) is known as utility in WTP space. WTP space models have the advantage of avoiding WTP estimates that are ratios of coefficients by estimating the coefficient on the ratio directly (Hensher and Greene, 2011; Train and Weeks, 2005). When the model is estimated in WTP space, estimates for the $\beta_{i}$ are estimates of marginal WTP for the attributes in $X$ (Hensher and Greene, 2011; Train and Weeks, 2005).

\subsection{Effects of Consequentiality}

This study hypothesizes that beliefs about consequentiality of survey responses on product offerings and WTP for a particular attribute are driven by three factors. First, the respondent may or may not believe their responses will have any bearing on the product attributes offered. Second, respondents may or may 
not place a high value on the underlying public policy or industry issue. Third, respondents might believe their survey response could affect product attribute change and also believe the underlying issue is important, but not believe that provision of the attribute would have a meaningful effect on the underlying issue. These three scenarios are investigated in this study.

First, to examine the effects of beliefs about consequentiality on WTP, interaction terms between belief in consequences of survey response and each attribute (Angus, Local, Traceable, Carbon, and Humane) are estimated and used along with the base coefficient for that attribute to obtain the WTP estimates for each attribute of steak and ground beef across both groups (Consequential $=0,1){ }^{1}$ There are theoretical and statistical-mechanical reasons why only attributes and variables that are functions of attributes enter the right-hand side of this model (Train, 2003). The experiment is designed to determine WTP for specific attributes; Consequentiality is not an attribute of the products per se. For the second reason, including a dummy variable for Consequentiality would introduce perfect collinearity because of the ASC. Therefore, the Consequential variable enters the equation indirectly through interactions with attributes. The variable Consequential is also interacted with ASC to examine whether the variable Consequential influenced respondents selecting none of the products in a choice set.

As a robustness check of directly estimated GMNL WTP, Hensher and Greene's (2005) procedure simulating WTP for mixed logit random parameter models is used. For the group indicating Consequential $=0$ and the $m$ th $=1$, $\ldots, 1,000$ draw, WTP is $\operatorname{WTP}_{k, m}^{C=0}=\beta_{k}^{m}+\eta_{k}^{m} \cdot z_{m, n}$, where $\left(\beta_{k}^{m}, \eta_{k}^{m}\right)$ are drawn from a multivariate normal distribution of all model parameters and their covariance using Krinsky and Robb's (1986) procedure. The $z_{k, m, n}, n=1$, $\ldots, 1,000$, are randomly drawn random variables from the standard normal distribution. The WTP for the Consequential $=1$ group is similarly determined as $W_{T} P_{k, m}^{C=1}=\beta_{k}^{m}+\delta_{k}^{m}+\left(\eta_{k}^{m}+\omega_{k}^{m}\right) \cdot z_{k, m, n}$, where $\left(\delta_{k}^{m}, \omega_{k}^{m}\right)$ are slope shifters for the Consequential group. The difference between groups is the median of $W_{T P} P_{k, m}^{C=1}-W T P_{k, m}^{C=0}$. We report the median values of the simulated distributions, with the lower 2.5 and upper 97.5 percentiles of the distributions for a $95 \%$ confidence interval.

Second, to determine respondents' belief of the importance of food prices relative to issues such as the environment, supporting farmers or local economies, humane treatment of animals, and safe supply of healthy food, respondents were presented a series of Likert-scale questions. These questions were asked to ascertain respondent views about food industry issues associated with extrinsic attributes having public goods aspects. Notably, respondents who value DNA traceability (Traceable) may place greater value on food safety. Individuals who value local foods (Local) may believe helping local economies or improving

1 A chi-square test of association did not reveal any significant association between believing a product outcome is likely and whether the respondent answered steak or ground beef choice sets. 
farmer incomes is important. Consumers who place greater value on a product labeled as Humane likely view humane treatment of animals as being important. Respondents who place greater value on use of GHG-reducing production practices (Carbon) likely view reducing the environmental impact of food production as being important. To measure how these views differ across beliefs about consequentiality, mean ratings of importance relative to keeping food prices low are compared with $t$-tests.

To examine respondent beliefs that provision of the attribute influenced the underlying public policy or industry issue, respondents were asked if they agreed with a statement that related an attribute to an underlying food policy or industry issue. Chi-square tests of association between agreement with each statement and Consequential $(0,1)$ groups are presented.

\section{Results}

The estimated GMNL models for steak and ground beef with Consequential interacted with each of the attributes are presented in Table 2. As indicated by the log likelihood ratio test of the overall model, the attribute levels and prices affect choice. For both models, the estimates of standard deviations for the attributes are all significant except for ConseqTraceable in the ground beef model and ConseqLocal in the steak model, suggesting use of random parameters is merited.

For the scaling portions of the models, the constants and coefficients on Education are significant, but the task number dummies are not. The positive coefficient on Education suggests that respondents with higher education levels are more certain about their choices across the choice sets. Because the coefficients on the task dummies are not significantly different from zero, this suggests no evidence of learning or survey fatigue across tasks. The estimated coefficient for $\theta_{0}$, a scaling parameter common to all respondents, is also significantly different from zero. The parameter $\tau$ is significant and positive in both models, suggesting scale heterogeneity across the set of respondent preferences.

\subsection{Attribute WTP}

For the ground beef model, each attribute variable and its interactions with Consequential are significant except for ConseqAngus, ConseqLocal, and ConseqASC. These results indicate respondent belief that their choices would affect the types of ground beef products offered does not increase WTP for Angus or locally produced ground beef. The lack of significance on the ASC interaction suggests that belief in consequentiality of choice does not significantly influence respondents selecting a "None" option in the ground beef choice sets. For the 
Table 2. Estimated Generalized Multinomial Logit Models of Ground Beef and Steak Choice, with Consequential-Attribute Interactions

\begin{tabular}{|c|c|c|c|c|c|c|}
\hline \multirow[b]{2}{*}{ Variable } & \multicolumn{3}{|c|}{ Ground Beef } & \multicolumn{3}{|c|}{ Steak } \\
\hline & $\begin{array}{l}\text { Estimated } \\
\text { Coefficient }\end{array}$ & $\begin{array}{l}\text { Standard } \\
\text { Error }\end{array}$ & & $\begin{array}{l}\text { Estimated } \\
\text { Coefficient }\end{array}$ & $\begin{array}{l}\text { Standard } \\
\text { Error }\end{array}$ & \\
\hline Price & -1.0000 & - & & -1.0000 & - & \\
\hline \multicolumn{7}{|l|}{ Mean } \\
\hline Angus & 1.2026 & 0.2306 & $* * *$ & 3.9985 & 0.3292 & $* * *$ \\
\hline Local & 0.9479 & 0.0807 & $* * *$ & 2.5838 & 0.2724 & $* * *$ \\
\hline Traceable & 0.1737 & 0.0604 & $* * *$ & 0.3954 & 0.1089 & $* * *$ \\
\hline Carbon & 0.1905 & 0.0405 & $* * *$ & 0.7898 & 0.1235 & $* * *$ \\
\hline Humane & 0.6545 & 0.0744 & $* * *$ & 1.7490 & 0.2502 & $* * *$ \\
\hline ASC & -3.7855 & 0.3047 & $* * *$ & -9.0572 & 0.2946 & $* * *$ \\
\hline ConseqAngus & 0.4472 & 0.2988 & & 2.2375 & 0.3771 & $* * *$ \\
\hline ConseqLocal & 0.1960 & 0.1223 & & 1.2545 & 0.3167 & $* * *$ \\
\hline ConseqTraceable & 0.2647 & 0.0874 & $* * *$ & 0.6934 & 0.2159 & $* * *$ \\
\hline ConseqCarbon & 0.2937 & 0.0729 & $* * *$ & 0.5429 & 0.2091 & $* * *$ \\
\hline ConseqHumane & 0.3384 & 0.1200 & $* * *$ & 1.2052 & 0.4043 & $* * *$ \\
\hline ConseqASC & -0.2184 & 0.2674 & & -1.3087 & 0.4940 & $* * *$ \\
\hline \multicolumn{7}{|l|}{ Heterogeneity } \\
\hline$\theta_{0}$ & 0.2576 & 0.2253 & & -0.8497 & 0.1569 & $* * *$ \\
\hline Education & 0.1571 & 0.0414 & $* * *$ & 0.1711 & 0.0488 & $* * *$ \\
\hline Task2 & -0.0866 & 0.2222 & & 0.1069 & 0.1934 & \\
\hline Task3 & -0.0914 & 0.2129 & & 0.2743 & 0.1836 & \\
\hline Task4 & 0.1378 & 0.2575 & & 0.0518 & 0.1982 & \\
\hline Task5 & 0.0409 & 0.2174 & & 0.1674 & 0.1994 & \\
\hline Task6 & -0.2002 & 0.2224 & & 0.0036 & 0.2397 & \\
\hline Task7 & -0.0305 & 0.1951 & & 0.0305 & 0.1959 & \\
\hline Task8 & -0.2087 & 0.2256 & & -0.0345 & 0.2237 & \\
\hline Task9 & -0.1249 & 0.2691 & & -0.1269 & 0.2024 & \\
\hline Task10 & -0.1064 & 0.2466 & & -0.2493 & 0.2230 & \\
\hline Task11 & -0.3072 & 0.2136 & & -0.2074 & 0.1933 & \\
\hline Task12 & -0.2130 & 0.2263 & & -0.2229 & 0.1919 & \\
\hline Task13 & -0.2810 & 0.2011 & & 0.2206 & 0.1737 & \\
\hline Task14 & 0.0837 & 0.2048 & & 0.0132 & 0.2463 & \\
\hline \multicolumn{7}{|l|}{ Standard deviation } \\
\hline Angus & 1.5692 & 0.1265 & $* * *$ & 5.0773 & 0.4213 & $* * *$ \\
\hline Local & 0.8598 & 0.0906 & $* * *$ & 2.5355 & 0.2260 & $* * *$ \\
\hline Traceable & -0.5404 & 0.0779 & $* * *$ & -1.1984 & 0.4377 & $* * *$ \\
\hline Carbon & -0.2496 & 0.0661 & $* * *$ & -0.9198 & 0.3006 & $* * *$ \\
\hline Humane & 0.8333 & 0.0922 & $* * *$ & 2.9312 & 0.2697 & $* * *$ \\
\hline$A S C$ & 3.4053 & 0.2103 & $* * *$ & 6.9253 & 0.3725 & *** \\
\hline ConseqAngus & 0.1316 & 0.0602 & $* *$ & -3.2421 & 0.3181 & $* * *$ \\
\hline ConseqLocal & 0.5379 & 0.1070 & $* * *$ & 0.8273 & 0.3602 & \\
\hline ConseqTraceable & 0.1305 & 0.1190 & & 1.6799 & 0.4785 & $* * *$ \\
\hline ConseqCarbon & 0.6428 & 0.0851 & $* * *$ & 0.8730 & 0.3854 & $* *$ \\
\hline ConseqHumane & 0.6988 & 0.1070 & $* * *$ & -1.2643 & 0.3627 & $* * *$ \\
\hline
\end{tabular}


Table 2. Continued

\begin{tabular}{|c|c|c|c|c|c|c|}
\hline \multirow[b]{2}{*}{ Variable } & \multicolumn{3}{|c|}{ Ground Beef } & \multicolumn{3}{|c|}{ Steak } \\
\hline & $\begin{array}{l}\text { Estimated } \\
\text { Coefficient }\end{array}$ & $\begin{array}{l}\text { Standard } \\
\text { Error }\end{array}$ & & $\begin{array}{l}\text { Estimated } \\
\text { Coefficient }\end{array}$ & $\begin{array}{l}\text { Standard } \\
\text { Error }\end{array}$ & \\
\hline ConseqASC & -0.4822 & 0.1369 & $* * *$ & -7.9015 & 0.3983 & $* * *$ \\
\hline$\tau$ & 0.8507 & 0.0494 & $* * *$ & 0.9692 & 0.0621 & $* * *$ \\
\hline $\mathrm{N}$ & 49,068 & & & 44,564 & & \\
\hline LLR $\chi^{2}$ & $2,861.90$ & $* * *$ & & $3,303.71$ & $* * *$ & \\
\hline
\end{tabular}

Notes: Asterisks $\left({ }^{* * *},{ }^{* *}\right.$, and $\left.{ }^{*}\right)$ indicate level of statistical difference from zero $(99 \%, 95 \%$, and $90 \%$, respectively). LLR, log likelihood ratio.

Table 3. Willingness to Pay (WTP) Estimates for Steak and Ground Beef, Medians and 95\% Confidence Intervals

\begin{tabular}{|c|c|c|c|c|c|c|}
\hline & \multicolumn{3}{|c|}{ Steak } & \multicolumn{3}{|c|}{ Ground Beef } \\
\hline & Median & $\begin{array}{l}\text { Lower } \\
\text { Bound }\end{array}$ & $\begin{array}{l}\text { Upper } \\
\text { Bound }\end{array}$ & Median & $\begin{array}{l}\text { Lower } \\
\text { Bound }\end{array}$ & $\begin{array}{l}\text { Upper } \\
\text { Bound }\end{array}$ \\
\hline \multicolumn{7}{|c|}{ Consequential $=0$} \\
\hline Angus & 4.00 & 3.27 & 4.74 & $1.21^{\mathrm{c}}$ & 1.05 & 1.63 \\
\hline Local & 2.59 & 2.02 & 3.17 & $0.95^{\mathrm{d}}$ & 0.89 & 1.12 \\
\hline Traceable & 0.40 & 0.16 & 0.63 & 0.17 & 0.13 & 0.29 \\
\hline Carbon & $0.79^{a}$ & 0.54 & 1.06 & 0.19 & 0.16 & 0.28 \\
\hline Humane & $1.75^{\mathrm{b}}$ & 1.21 & 2.31 & 0.66 & 0.60 & 0.82 \\
\hline \multicolumn{7}{|c|}{ Consequential $=1$} \\
\hline Angus & 6.26 & 5.63 & 6.90 & $1.65^{\mathrm{c}}$ & 1.56 & 1.97 \\
\hline Local & 3.86 & 3.26 & 4.43 & $1.15^{\mathrm{d}}$ & 1.07 & 1.36 \\
\hline Traceable & 1.08 & 0.71 & 1.44 & 0.44 & 0.39 & 0.57 \\
\hline Carbon & $1.34^{\mathrm{a}}$ & 0.99 & 1.65 & 0.49 & 0.44 & 0.60 \\
\hline Humane & $2.99^{b}$ & 2.16 & 3.78 & 1.00 & 0.92 & 1.22 \\
\hline \multicolumn{7}{|l|}{ Difference } \\
\hline Angus & 2.26 & 1.50 & 3.02 & 0.45 & 0.26 & 1.04 \\
\hline Local & 1.25 & 0.66 & 1.86 & 0.19 & 0.11 & 0.45 \\
\hline Traceable & 0.69 & 0.25 & 1.13 & 0.27 & 0.21 & 0.42 \\
\hline Carbon & 0.54 & 0.11 & 0.96 & 0.29 & 0.24 & 0.44 \\
\hline Humane & 1.22 & 0.43 & 2.04 & 0.34 & 0.26 & 0.57 \\
\hline
\end{tabular}

Notes: Monte Carlo estimates ( $m=1,000$ draws). The superscripted letters a, b, c, and d indicate WTP was not different at the $5 \%$ level across Consequential for each respective product.

steak model, all of the base coefficients for the attributes and their interactions are significant.

The simulated WTP closely approximates WTP estimated directly by the GMNL model. The median WTP values for each attribute are compared across consequentiality beliefs using $95 \%$ confidence intervals (Table 3). Overall, premiums are highest for Angus, followed by Local and Humane for both steak and ground beef (Table 3). DNA traceability exhibits the lowest premiums. These results suggest that respondents are most willing to pay for attributes 
with private benefits (Angus) and those with more familiar labeling regimes (i.e., Local). The finding of positive WTP for Angus is similar to the results of Feldkamp, Schroeder, and Lusk (2005), Froehlich, Carlberg, and Ward (2009), and Lusk and Schroeder (2004). As with our results, previous research has found WTP premiums for locally produced beef (Adalja et al., 2015; Chang et al., 2013). Among those with more public benefits, the Humane attribute exhibits the highest WTP. Hence as with prior studies (Carlsson, Frykblom, and Lagerkvist, 2007; Dickinson, Hobbs, and Bailey, 2003; Lagervist and Hess, 2011; Lijenstolpe, 2008), consumers were found to exhibit positive WTP for humane animal treatment, in this case for beef cattle.

As with results from studies by Herriges et al. (2010), Vossler and Watson (2013), Vossler, Doyon, and Rondeau (2012), Nepal, Berrens, and Bohara (2009), and Interis and Petrolia (2014), consequentiality influenced WTP for certain attributes. Belief that survey responses would affect the types of beef products offered significant increases in median WTP for each steak attribute except Carbon and Humane. The largest difference appears to be for Angus at \$2.26 per pound, followed by Local at $\$ 1.27$ per pound. For ground beef, consequentiality increases WTP for each attribute except Angus and Local. The largest differences among those statistically different for ground beef are Humane $(\$ 0.34$ per pound) followed by Carbon (\$0.30 per pound).

Additionally, using the information from Table 3, if the confidence intervals around the median WTP are calculated as a percentage of the median, they tend to be much wider percentage-wise for the group that does not believe the survey responses will be consequential than for those who do believe it. The only exception is for Local in ground beef. This result suggests much more certainty about WTP among those in the group that believes their responses will be consequential. Hence, beliefs in consequentiality affect not only the level of WTP, but also the variability of responses regarding WTP. These results suggest that credible information about how the survey results will be used can affect WTP level and the heterogeneity across WTP estimates.

As might be expected, the confidence intervals as a percentage of the median are larger for Angus, in ground beef than in steak, suggesting much more consistency in WTP for Angus in steaks. However, for a number of the attributes, the confidence intervals as a percentage of the median are smaller for ground beef than for steak, suggesting that ground beef consumers are more consistent in their WTP for Local, Traceable, and Humane. These results suggest future research to examine how the steak and ground beef respondents differ.

\subsection{Ex Post Association between Consequentiality and Attributes}

We examine two additional components of beliefs about food industry issues that are related to the attributes considered. First, we examine the importance of several food industry issues relative to keeping food prices low (e.g., supporting farm incomes relative to keeping food prices low) to the respondents. Second, 
Table 4. Opinion Ratings about Food Industry Issues Relative to Low Food Prices across Consequential

\begin{tabular}{|c|c|c|c|c|}
\hline \multirow{3}{*}{$\begin{array}{l}\text { Keeping Food Prices Low Is } \\
\text { More Important Than }\end{array}$} & \multicolumn{4}{|c|}{$\begin{array}{c}\text { Mean Rating } \\
(1=\text { strongly disagree, } \ldots, 5=\text { strongly agree }) \\
(\mathrm{n}=1,631)\end{array}$} \\
\hline & \multicolumn{2}{|c|}{ Consequential = } & \multirow[b]{2}{*}{$t$-Statistic } & \\
\hline & 1 & 0 & & \\
\hline $\begin{array}{l}\text { Providing safe, healthy, and } \\
\text { nutritious food choices }\end{array}$ & 1.9709 & 2.0260 & 1.111 & \\
\hline $\begin{array}{l}\text { Providing reasonable incomes } \\
\text { for U.S. farmers }\end{array}$ & 2.3847 & 2.4808 & 2.051 & $* *$ \\
\hline $\begin{array}{l}\text { Ensuring humane treatment of } \\
\text { animals used in food } \\
\text { production }\end{array}$ & 2.4854 & 2.6366 & 2.830 & $* * *$ \\
\hline Supporting my local economy & 2.4976 & 2.6279 & 2.684 & *** \\
\hline $\begin{array}{l}\text { Reducing the environmental } \\
\text { impact of food production }\end{array}$ & 2.9029 & 3.0779 & 3.422 & *** \\
\hline
\end{tabular}

Note: Asterisks $\left(* * *, * *\right.$, and $\left.{ }^{*}\right)$ indicate statistical significance level of difference between the means $(99 \%$, $95 \%$, and $90 \%$, respectively).

we examine whether respondents believed these food attributes would affect an associated public policy/food industry issue (e.g., whether local foods would benefit family farms).

Table 4 summarizes the importance ratings for several public policy/food industries issues relative to keeping food prices low. The issue that was more important relative to keeping food prices low was providing safe, health, and nutritious food choices, followed by providing reasonable incomes for farmers, ensuring humane animal treatment, supporting the local economy, and then reducing the environmental impact of food production. Based on these results, one might expect that WTP for the attributes might be ordered in magnitude as Traceable, Local, Humane, and then Carbon. However, as stated earlier, the ordering of magnitudes for non-Angus attributes was Local, Humane, Carbon, and then Traceable.

The relationship between Consequential and the importance of these food industry issues is examined in Table 4. Respondents who believed the survey response would be at least somewhat likely to affect the types of beef products offered maintained different views about the importance of food industry issues relative to low prices compared with those who did not. In particular, respondents who did not believe the survey was at least somewhat likely to be consequential were more likely to agree that food price is more important than issues such as farmer incomes, humane treatment of animals, supporting the local economy, and reducing the environmental impact of the food industry. However, no statistical differences in ratings were determined across the two groups for the importance 
Table 5. Opinions about Food Attributes and Food Policy/Industry Issues across Consequential

\begin{tabular}{llll}
\hline \hline & \multicolumn{3}{c}{ Percent Agreeing with Statement $(\mathrm{n}=1,633)$} \\
\cline { 2 - 4 } $\begin{array}{l}\text { Statement about Attribute and } \\
\text { Food Policy/Industry Issue }\end{array}$ & 1 & 0 & $\chi^{2}$ \\
\hline $\begin{array}{l}\text { Angus beef is better tasting } \\
\begin{array}{l}\text { DNA traceable beef is safer to } \\
\quad \text { eat }\end{array}\end{array}$ & 61.45 & 59.53 & 0.6329 \\
$\begin{array}{l}\text { The U.S. food supply is safe and } \\
\text { reliable }\end{array}$ & 57.61 & 33.79 & 20.0378 \\
$\begin{array}{l}\text { Raised carbon friendly beef is } \\
\text { more environmentally friendly }\end{array}$ & 65.70 & 53.84 & 2.1650 \\
$\begin{array}{l}\text { Local products are better for } \\
\text { family farms }\end{array}$ & 56.73 & 62.50 & 1.8134 \\
$\begin{array}{l}\text { Local products are better for the } \\
\quad \text { local economy }\end{array}$ & 70.06 & 70.74 & 5.8816 \\
$\begin{array}{l}\text { Food animals are generally } \\
\text { treated humanely by farmers }\end{array}$ & 43.27 & 41.09 & 0.1049 \\
$\begin{array}{l}\text { Food animals are generally } \\
\text { treated humanely by handlers } \\
\text { and processors }\end{array}$ & 27.76 & 24.63 & 0.7980 \\
\hline \hline
\end{tabular}

Note: Asterisks (***, ${ }^{* *}$, and $\left.{ }^{*}\right)$ indicate statistically significant degree of association with Consequential at confidence levels of $99 \%, 95 \%$, and $90 \%$, respectively.

of low food prices relative to a safe and healthy food supply system. In each case, respondents who believed their choices could affect product offerings placed less importance on food price relative to each food industry issue, except for food safety. These results suggest that respondents who believed the survey would have an effect on product offerings were more likely to feel strongly about several nonprice food issues, such as supporting farm incomes or local economies, humane treatment of animals, and the environmental footprint of food production.

With respect to the food attribute and the food policy or food industry issue, the highest percentage of respondents agree that local products are better for the local economy, followed by "Raised carbon friendly beef is more environmentally friendly" and "Angus beef is better tasting" (Table 5). Respondents were less likely to believe that handlers and processors generally treat food animals humanely. When differences across beliefs about product outcomes are incorporated, it is evident that two variables are statistically associated with this consequentiality belief. These are "DNA traceable beef is safer to eat" and "Local products are better for family farms." Although nearly $45 \%$ of those believing their responses were consequential felt that DNA traceable beef was safer, less than $34 \%$ of those not believing in consequentiality felt it was safer. In addition, nearly $57 \%$ of the Consequential $=1$ group felt that local products improved the financial position of family farms, whereas 
less than $51 \%$ of individuals in the Consequential $=0$ group felt that local products were better for family farm businesses. These results suggest that beliefs in consequentiality are linked to beliefs about the effectiveness of providing the product attributes to address food industry issues including DNA traceability affecting food safety or local foods helping to support local farms. No statistical association was found between consequentiality and agreement with the other food policy/industry issues (e.g., taste, general food safety, environmental friendliness, impact on local economies, and humane treatment of animals).

Based on the results in Table 5, if confidence in an attribute or the industry addressing an underlying food industry issue was assumed to drive WTP for the attributes, then Local, Angus, Humane, and Carbon would have relatively high WTP values. This bears out in the case of Local, Angus, and Humane, but not Carbon. The lowest levels of agreement were for DNA traceable beef being safer to eat. This result suggests that respondents do not have a high confidence in DNA traceability to ensure a safer beef supply chain and end product.

Further investigation into the drivers of product consequentiality beliefs reveals that although respondents with product consequentiality beliefs tend to place greater importance on certain food industry issues relative to food prices, they were less certain about the ability of an attribute to effect changes in food policy or broader industry issues. Belief in product consequentiality appears to be associated with placing greater importance on the underlying issues of providing reasonable farm incomes, supporting the local economy, humane treatment of animals, and reducing environmental impacts. However, the association between belief in consequentiality and product attributes providing some resolution to the underlying issues appears less certain, with only DNA traceability and provision of food safety, along with local and provision of improved family farm income, being associated with belief in response consequentiality. These beliefs appeared to translate into additional WTP for Local and Traceable in steak and Traceable in ground beef.

When we incorporate the WTP levels for the attributes along with importance of the underlying issues and belief in the industry or attribute to address the underlying issue, several patterns emerge. Angus exhibited the highest WTP. Though we asked respondents to hold all other quality characteristics constant, it is likely that they believe Angus tastes better. Beyond Angus, which embodies mostly private benefits, Local and Humane, which include public benefits, also exhibited relatively high WTP values. The underlying issues for both of these attributes were important to respondents relative to keeping food prices low, as shown in Table 4. Furthermore, more than $70 \%$ believed local products are better for the economy and that food animals are not generally treated humanely by processors and handlers. However, when we turn to the Traceable and Carbon attributes, the WTP values were lower. Although providing safe choices was a high priority for respondents, respondents were not confident in DNA traceability to improve beef food safety. With respect to Carbon, although 
respondents believed that beef raised and processed using the practices described would decrease GHG emissions and would be more environmentally friendly, they did not place a high priority on reducing the environmental impact of food production.

\section{Conclusions}

The results from this study suggest that consumers are willing to pay premiums for extrinsic attributes of ground beef and steak. Leading in terms of the dollar amount, consumers place the largest premium on Angus certification, with most believing that Angus tastes better. However, among other nonprice or taste attributes, the next largest premiums are for locally produced beef. Among the issues that rated highest in importance compared with lower prices, supporting farm income came in second behind providing safe foods. Hence, food safety and local economy are issues that consumers appear most concerned about relative to low food prices. As for labels or attributes affecting industry issues, more than $70 \%$ of respondents agreed that local food products improve local economies. Not only did "produced local" labels receive relatively high premiums, but supporting farm income was relatively important to the respondents who believed purchase of local foods boosts local economies.

Interestingly, although a high percentage believed "raised carbon friendly" beef would be better for the environment, consumers rated reducing the environmental footprint of food production relatively low compared with keeping food prices low. In addition, although consumers viewed this labeling and production regime as potentially effective, they did not view it as a high priority compared with other issues. In this case, priority overshadowed effectiveness in consumers assigning premiums to that attribute. Although food safety is a high priority, a relatively low percentage of respondents believed DNA traceable beef is safer to eat. Consumers viewed it as a high priority to keep foods safe but were unconvinced that a DNA traceability program would actually serve to provide safer beef; thus, beliefs about effectiveness overshadowed those about the priority of food safety, resulting in low premiums for DNA traceable beef. Respondents who believed in survey response consequentiality did, however, exhibit higher premiums for DNA traceability than those who did not for both ground beef and steak.

Although inclusion of several extrinsic attributes enables industry comparison of which labeling regimes will potentially carry the highest premiums, it is helpful to understand also the underlying reasons why some labels receive higher or lower premiums. The results from this study provide some of those potential insights to the WTP literature on preferences for beef. The results also highlight the need to provide information about why respondents may believe in consequentiality of their response and why this belief may influence their WTP for a product rather than simply including a consequentiality variable in a 
model of extrinsic attribute choice. Responses to the survey may be influenced by respondent views on whether the survey results will be translated into concrete product offerings (industry response), whether the underlying issue is of importance to consumers, and whether consumers believe provision of the attribute will ameliorate the issue or problem.

We asked respondents to assume that all other product attributes were identical except for the attributes in the choice sets, but it is likely that consumers maintain preconceptions about the quality of the example products presented to them. It is therefore important to note that these results reflect an average over these underlying assumptions on the part of respondents about the quality of the ground beef or steak. In addition, we asked a question regarding consequentiality of the survey responses regarding industry product offerings. A potential limitation of this research is the use of a single indicator variable to measure beliefs in consequentiality. The current study examined beliefs that survey responses would influence the beef industry to change its product offerings. Future research could hypothesize that belief in consequentiality may vary across attributes. Consumers may believe the industry might be more likely to provide certain attributes over others in response to survey results.

Future research might incorporate specific questions about consequentiality of the survey responses with respect to offering each of the attributes in the products. Furthermore, additional research could compare WTP for the extrinsic attributes across both products for the group of individuals that indicated they consume both steaks and ground beef and were randomly assigned to either product's choice sets.

\section{References}

Abidoye, B., H. Bulut, J. Lawrence, B. Mennecke, and A. Townsend. "U.S. Consumers' Valuation of Quality Attributes in Beef Products." Journal of Agricultural and Applied Economics 43,1(2011):1-12.

Adalja, A., J. Hanson, C. Towe, and E. Tselepidakis. "An Examination of Consumer Willingness to Pay for Local Products." Agricultural and Resource Economics Review 44,3(December 2015):253-74.

Adamowicz, W., P. Boxall, M. Williams, and J. Louviere. "Stated Preference Approaches for Measuring Passive Use Values: Choice Experiments and Contingent Valuation." American Journal of Agricultural Economics 80,1(1998):64-75.

American Humane Association. "About Our Program." Internet site: http://www. humaneheartland.org/about-us (Accessed March 28, 2017).

Animal Welfare Approved. "About.” Internet site: https://animalwelfareapproved.us/about/ (Accessed March 28, 2017).

Aylward, L. "Graze Craze: The Market for Grass-Fed Beef.” Food Business News. April 15, 2015. Internet site: http://www.foodbusinessnews.net/articles/news_home/Consumer_ Trends/2015/04/Graze_craze_The_market_for_gra.aspx?ID=\% 7BF0218882-5B024ABE-8286-9C960D64164C\%7D (Accessed May 22, 2017). 
Bussard, J. 2016. "Grass-Fed Growth Brings Challenges, Opportunity and a Few Fringe Benefits.” Beef. February 4, 2016. Internet site: http://www.beefmagazine.com/pasturerange/grass-fed-growth-brings-challenges-opportunity-and-few-fringe-benefits (Accessed May 22, 2017).

Carlsson, F., P. Frykblom, and C. Lagerkvist. "Consumer Willingness to Pay for Farm Animal Welfare: Mobile Abattoirs versus Transportation to Slaughter." European Review of Agricultural Economics 34,3(2007):321-44.

Carson, R.T., and T. Groves. "Incentive and Informational Properties of Preference Questions." Environmental and Resource Economics 37,1(2007):181-210.

Carson, R.T., T. Groves, and J.A. List. "Consequentiality: A Theoretical and Experimental Exploration of a Single Binary Choice Source." Journal of the Association of Environmental and Resource Economists 1,1/2(2014):171-207.

Chang, K.-L., P. Xu, K. Underwood, C. Maen, and G. Langelett. “Consumers' Willingness to Pay for Locally Produced Ground Beef: A Case Study of the Rural Northern Great Plains." Journal of International Food and Agribusiness Marketing 25,1(2013):4267.

Cicia, G., and F. Colantuoni. "Willingness to Pay for Traceable Meat Attributes: A Metaanalysis." International Journal on Food System Dynamics 1,3(2010):252-63.

Clark, C., and C. Russell. "Public Information Provision as a Tool of Environmental Policy." Environment, Information and Consumer Behavior. S. Krarup and C. Russell, eds. Northampton, MA: Edward Elgar, 2005, pp. 111-40.

Cummings, R., and L. Taylor. "Unbiased Value Estimates for Environmental Goods: A Cheap Talk Design for the Contingent Valuation Method." American Economic Review 89,3(1999):649-65.

Czajkowski, M., M. Giergiczny, and W. Greene. "Learning and Fatigue Effects Revisited: Investigating the Effects of Accounting for Unobservable Preference and Scale Heterogeneity." Land Economics 90,2(2014):324-51.

Darby, M.R., and E. Karni. "Free Competition and the Optimal Amount of Fraud." Journal of Law and Economics 16,1(1973):67-88.

Dennis, M. Consumer Preferences for Beef Products Produced Using Low-Carbon Practices. Project Report. New York: GfK Custom Research LLC, 2013.

Dickinson, D.L., J.E. Hobbs, and D. Bailey. “A Comparison of U.S. and Canadian Consumers' Willingness to Pay for Red-Meat Traceability.” Economic Research Institute Study Papers, 264. Logan: Utah State University, 2003.

Doherty, E., and D. Campbell. "Demand for Safety and Regional Certification of Food: Results from Great Britain and the Republic of Ireland.” British Food Journal 116,4(2014):67689.

Feldkamp, T.J., T.C. Schroeder, and J.L. Lusk. "Determining Consumer Valuation of Differentiated Beef Steak Quality Attributes.” Journal of Muscle Foods 16,1(2005):115.

Fiebig, D., M. Keane, J. Louviere, and N. Wasi. "The Generalized Multinomial Logit Model: Accounting for Scale and Coefficient Heterogeneity." Marketing Science 29,3(2010):393-421.

Froehlich, E.J., J.G. Carlberg, and C.E. Ward. "Willingness-to-Pay for Fresh Brand Name Beef." Canadian Journal of Agricultural Economics 57,1(2009):119-37.

Galimberti, A., F. De Mattia, A. Losa, I. Bruni, S. Federici, M. Casiraghi, S. Martellows, and M. Labra. "DNA Barcoding as a New Tool for Food Traceability." Food Research International 50,1(2013):55-63. 
Golan, E., B. Kissoff, and F. Kuchler. "Food Traceability: One Ingredient in a Safe and Efficient Food Supply." Amber Waves 2,2(2004):14-21.

Golan, E., T. Roberts, and M. Ollinger. "Savvy Buyers Spur Food Safety Innovations, in Meat Processing." Amber Waves 2,2(2004):22-29.

Greene, W.H., and D.A. Hensher. "Does Scale Heterogeneity across Individuals Matter? An Empirical Assessment of Alternative Logit Models." Transportation 37,3(2010): 413-28.

. "Revealing Additional Dimensions of Preference Heterogeneity in a Latent Class Mixed Multinomial Logit Model.” Empirical Economics 45,14(2013):1897-902.

Groothuis, P., T. Mohr, J. Whitehead, and K. Cockerill. "Endogenous Consequentiality in Stated Preference Referendum Data: The Influence of the Randomly Assigned Tax Amount." Land Economics 93,2(2017):258-68.

Halbrook, S.A., W.J. Armbruster, and M.M. Thompson. "The Future of Animal Agriculture in North America." Choices 21,3(2006):155-57.

Henchion, M., M. McCarthy, V.C. Resconi, and D. Troy. "Meat Consumption: Trends and Quality Matters.” Meat Science 98,3(2014):561-68.

Hensher, D., and W. Greene. Applied Choice Analysis. Cambridge: Cambridge University Press, 2005.

- "Valuation of Travel Time Savings in WTP and Preference Space in the Presence of Taste and Scale Heterogeneity." Journal of Transportation Economics and Policy 45,3(2011):505-25.

Herriges, J., C. Kling, C.-C. Liu, and J. Tobias. "What Are the Consequences of Consequentiality?” Journal of Environmental Economics and Management 59,1(2010):67-81.

Hobbs, J., D. Bailey, and M. Haghiri. "Traceability in the Canadian Red Meat Sector: Do Consumers Care?” Canadian Journal of Agricultural Economics 53,1(2005):47-65.

Humane Farm Animal Care. "Our Standards.” Internet site: http://certifiedhumane.org/ how-we-work/our-standards/ (Accessed January 29, 2017).

Hurley, S., D. Miller, and J. Kliebenstein. "Estimating Willingness to Pay Using a Polychotomous Choice Function: An Application to Pork Products with Environmental Attributes." Journal of Agricultural and Resource Economics 31,2(2006):301-17.

Hwang, J., D. Petrolia, and M. Interis. "Consequentiality and Opt-Out Responses in Stated Preference Surveys.” Agricultural and Resource Economics Review 43,3(2014):471-88.

Interis, M., and D. Petrolia. "The Effects of Consequentiality in Binary- and MultinomialChoice Surveys." Journal of Agricultural and Resource Economics 39,2(2014):201-16.

Kennedy, P., B. Laplante, and J. Maxwell. "Pollution Policy: The Role for Publicly Provided Information." Journal of Environmental Economics and Management 26,1(1994):3143.

Krinsky, I., and A.L. Robb. "On Approximating the Statistical Properties of Elasticities." Review of Economic and Statistics 68,4(1986): 715-19.

Lagervist, C., and S. Hess. "A Meta-Analysis of Consumer Willingness to Pay for Farm Animal Welfare." European Review of Agricultural Economics 38,1(2011):55-78.

Lancaster, K. Consumer Demand: A New Approach. New York: Columbia University Press, 1972.

Lee, J.Y., D. Han, R. Nayga, and S. Lim. "Valuing Traceability of /Imported Beef in Korea: An Experimental Auction Approach." Australian Journal of Agricultural and Resource Economics 55,3(2011):360-73.

Liljenstolpe, C. "Evaluating Animal Welfare with Choice Experiments: An Application to Swedish Pig Production.” Agribusiness 24,1(2008):67-84. 
List, J.A. "Do Explicit Warnings Eliminate the Hypothetical Bias in Elicitation Procedures? Evidence from Field Auctions for Sports Cards." American Economic Review 91,5(2001):1498-507.

Loomis, J. "Strategies for Overcoming Hypothetical Bias in Stated Preference Surveys." Journal of Agricultural and Resource Economics 39,1(2014):34-46.

Loureiro, M.L., and W.J. Umberger. "A Choice Experiment Model for Beef: What Us Consumer Responses Tell Us about Relative Preferences for Food Safety, Country-ofOrigin Labeling and Traceability." Food Policy 32,4(2007):496-514.

Louviere, J.J. "Conjoint Analysis Modelling of Stated Preferences: A Review of Theory, Methods, Recent Developments and External Validity." Journal of Transport Economics and Policy 22,1(1988):93-119.

Lusk, J.L., J. Roosen, and J.A. Fox. "Demand for Beef from Cattle Administered Growth Hormones or Fed Genetically Modified Corn: A Comparison of Consumers in France, Germany, the United Kingdom, and the United States." American Journal of Agricultural Economics 85,1(2003):16-29.

Lusk, J.L., and T.C. Schroeder. "Are Choice Experiments Incentive Compatible? A Test with Quality Differentiated Beef Steaks?" American Journal of Agricultural Economics 86,2(2004):467-82.

Martinez, S., M. Da Pra, S. Pollack, K. Ralston, T. Smith, S. Vogel, S. Clark, L. Lohr, S. Low, and C. Newman. Local Food Systems: Concepts, Impacts, and Issues. Washington, DC: U.S. Department of Agriculture, Economic Research Service, Economic Research Report No. 97, 2010.

McFadden, D. "Contingent Valuation and Social Choice." American Journal of Agricultural Economics 76,4(1994):689-708.

McGarry Wolf, M., and S. McLennan. "Local Meat Brands Attract Consumer Demand." Journal of Food Distribution Research 48,1(2017):111-12.

Mennecke, B.E., A.M. Townsend, D.J. Hayes, and S.M. Lonergan. "A Study of the Factors that Influence Consumer Attitudes Toward Beef Products Using the Conjoint Market Analysis Tool." Journal of Animal Science 85,10(2007):2639-59.

Moe, T. "Perspectives on Traceability in Food Manufacture." Trends in Food Science and Technology 9,5(1998):211-14.

Mitchell, R., and R. Carson. Using Surveys to Value Public Goods: The Contingent Valuation Method. Washington, DC: Resources for the Future, 1989.

Nepal, M., R.P. Berrens, and A.K. Bohara. "Assessing Perceived Consequentiality: Evidence from a Contingent Valuation Survey on Global Climate Change.” International Journal of Ecological Economics and Statistics 14,P09(2009):14-29.

Ollinger, M., J. Guthrie, and J. Bovay. The Food Safety Performance of Ground Beef Suppliers to the National School Lunch Program. Washington, DC: U.S. Department of Agriculture, Economic Research Service, Economic Research Report No. 180, 2014.

Petrolia, D., W. Walton, and L. Yehouenou. "Is There a Market for Branded Gulf of Mexico Oysters?" Journal of Agricultural and Applied Economics 49,1(2017):45-65.

Steiner, B., F. Gao, and J. Unterschultz. "Alberta Consumers' Valuation of Extrinsic and Intrinsic Red Meat Attributes: A Choice Experimental Approach.” Canadian Journal of Agricultural Economics 58,2(2010):171-89.

Tonsor, G.T., and R. Shupp. "Valuations of 'Sustainably Produced' Labels on Beef, Tomato, and Apple Products." Agricultural and Resource Economics Review 38,3(2009): 37183.

Train, K. Discrete Choice Methods with Simulation. New York: Oxford University Press, 2003. 
Train, K., and M. Weeks. "Discrete Choice Models in Preference Space and Willingnessto-Pay Space." Applications of Simulation Methods in Environmental and Resource Economics. R. Scarpa and A. Alberini, eds. Dordrecht, the Netherlands: Springer, 2005, pp. 1-16.

U.S. Department of Agriculture, Agricultural Marketing Service (USDA-AMS). Live Animal Specification: American Angus Association's Specification for Characteristics of Cattle Eligible for Approved Beef Programs Claiming Angus Influence. Washington, DC: USDA-AMS, 2017a. Internet site: https://www.ams.usda.gov/sites/default/files/media/ AAALiveAnimalSpecification.pdf (Accessed March 5, 2017).

- National Retail Report - Beef. Washington, DC: USDA-AMS, 2017b. Internet site: https://www.ams.usda.gov/mnreports/lswbfrtl.pdf (Accessed January 29, 2017).

U.S. Department of Agriculture, Natural Resources Conservation Service (USDA-NRCS). Conservation Practice Standard Prescribed Grazing, Code 528. Washington, DC: USDANRCS, 2010. Internet site: https://www.nrcs.usda.gov/Internet/FSE_DOCUMENTS/ stelprdb1045100.pdf (Accessed January 28, 2017).

U.S. Environmental Protection Agency (EPA). Inventory of U.S. Greenhouse Gas Emissions and Sinks: 1990-2013. Washington, DC: EPA, 2015.

Verbeke, W., and R. Ward. "Consumer Interest in Information Cues Denoting Quality, Traceability and Origin: An Application of Ordered Probit Models to Beef Labels.” Food Quality and Preference 17,6(2006):465-67.

Vermeulen, B., P. Goos, and M. Vanderbroek. "Models and Optimal Designs for Conjoint Choice Experiments Including a No-Choice Option." International Journal of Research in Marketing 25,2(2008):94-103.

Vestal, M.K., J.L. Lusk, E.A. DeVuyst, and J.R. Kropp. "The Value of Genetic Information to Livestock Buyers: A Combined Revealed, Stated Preference Approach.” Agricultural Economics 44,3(2013):337-47.

Vossler, C.A., M. Doyon, and D. Rondeau. "Truth in Consequentiality: Theory and Field Evidence on Discrete Choice Experiments." American Economic Journal: Microeconomics 4,4(2012):145-71.

Vossler, C.A., and S.B. Watson. "Understanding the Consequences of Consequentiality: Testing the Validity of Stated Preferences in the Field." Journal of Economic Behavior and Organization 86(February 2013):137-47.

Weaber, R.L., and J.L. Lusk "The Economic Value of Improvements in Beef Tenderness by Genetic Marker Selection.” American Journal of Agricultural Economics 92,5(2010):145671.

White, R.R., and M. Brady. "Can Consumers' Willingness to Pay Incentivize Adoption of Environmental Impact Reducing Technologies in Meat Animal Production?" Food Policy 49(December 2014):41-49. 